\title{
Effect of Dietary Supplementation of Methionine on Growth, Survival and Immune Response of Indian Major Carp, Labeo rohita
}

\author{
Nilima Priyadarshini ${ }^{*}$, H. Shivananda Murthy, A. Hosseinpoor Zelaty and H. Swain \\ Department of Aquaculture College of Fisheries Mangalore, Karnataka-575002, India \\ *Corresponding author
}

\section{A B S T R A C T}

\section{Keywords}

Methionine, Labeo rohita, SGR and FCR

Article Info

Accepted:

20 January 2018

Available Online:

10 February 2018
The study was conducted in Cement cisterns of $25 \mathrm{~m}^{3}$ size $(5 \times 5 \times 1 \mathrm{~m})$ with soil base to evaluate the effect of methionine, which is the indispensable amino acid on growth, survival and immune response of Indian major carp, Labeo rohita. The uniform size groups (109.07 $\pm 2.6758 \mathrm{~g}$ ) of rohu juveniles were used for the study. The study was carried out in five replicate groups for a period of 60 days. Fishes were stocked at the rate of 10 per tank. Two test diets namely $\mathrm{T}_{1}$ and $\mathrm{T}_{2}$ with $30 \%$ protein level were formulated. Diet $\mathrm{T}_{1}$ had $0.08 \%$ and $\mathrm{T}_{2}$ had $0.48 \%$ methionine, and diet without methionine supplementation served as a control $\left(\mathrm{T}_{0}\right)$. Significant differences were evident between treatment groups $(\mathrm{P}<0.05)$ in growth parameters, SGR, FCR. Among the tested doses $0.48 \%$ methionine showed better results than $0.08 \%$ methionine inclusion in the fish diet. Results of this study indicate that the best overall growth, survival and feed utilization of rohu fingerlings and juveniles were obtained with $0.48 \%$ methionine supplementation.

\section{Introduction}

Fish is a vital component of the human food supply and man's most important source of high-quality animal protein. Global fish production stood at 158 million tonnes in 2012 and fish consumption accounts for $17 \%$ of the global population's intake of animal protein which provides essential nutrients, vitamins and Omega-3 fatty acids, according to the Food and Agriculture Organization (FAO) State of World Fisheries and Aquaculture report released in 2014. While the global consumption of fish was $19 \mathrm{~kg}$ per person per year in 2012, for India it was $8 \mathrm{~kg}$. The fisheries sector contributed $0.8 \%$ to India's gross domestic product (GDP) and $4.8 \%$ of the agriculture GDP in 2012-13. The global commercial production for human use of fish and other aquatic organisms occurs in two ways: they are either captured wild by commercial fishing or they are cultivated and harvested using aquacultural and farming techniques.

Among the Indian major carps, Labeo rohita, popularly known as "rohu", is one of the most widely cultured and preferred species in the country and commands higher price in the market. It is the natural inhabitant of freshwater sections of the rivers and thrives well in all fresh waters below an altitude of approximately $549 \mathrm{~m}$. Rohu is a bottom feeder and prefers to feed on plant matter including 
decaying vegetation and attains maturity towards the end of the second year in ponds. The spawning season of rohu generally coincides with the southwest monsoon. Spawning takes place in flooded rivers. The fecundity of rohu varies from 226,000 to $2,794,000$, depending upon the length and weight of the fish and weight of the ovary. The spawn of this fish is collected from rivers during monsoon and reared in tanks and lakes (Talwar and Jhingran, 1991). The economic success of fish culture depends on the cost of feeds, particularly the cost of protein materials incorporated into the feed. Prepared diets not only provide the essential nutrients that are required for normal physiological functioning but also may serve as a medium by which fish receive certain compounds that can alter endocrine activity, immunity and other physiological responses (Gatlin, 2002; Li et al., 2005). Thus, in recent years there have been increased research efforts in developing dietary supplementation strategies, in which various growth promoting compounds like amino acids have been evaluated. Hence, the present study was undertaken to examine the optimum methionine requirements for juvenile rohu.

Protein is a major constituent of animal body. A liberal and continuous supply of protein is needed throughout life. The primary aim of fish culture is to efficiently transform dietary protein into tissue protein. Natural diets of fish are rich in protein. Generally, fish require a high percentage of protein in the diet than birds and mammals. This may be because, fishes utilize carbohydrates less efficiently. Therefore, some dietary protein may be metabolized for energy. The amount of dietary protein required by fishes is directly influenced by the indispensable amino acid pattern in the diet. The amount of protein needed to produce maximum growth has been investigated with purified test diets (H S Murthy, 1995, 1998; NRC, 1983).
In formulated feeds, protein is the most expensive component. Protein is a complex organic molecule consisting of more than twenty amino acids. When ingested protein is digested, amino acids are released into the body pool. They are absorbed for tissue protein synthesis. Methionine is one of the essential amino acids needed for good growth and health, but cannot be produced in the body, and so must be provided through the diet. It is a sulphur containing amino acid for growth of young fish (Wilson, 1989) and terrestrial animals (Visek, 1984). Quantitative dietary methionine requirements for several fish species have been shown to depend on dietary cystine concentrations. Cystine can substitute for a part of methionine requirement, since conversion of methionine to cystine is a common path way of intermediary metabolism in many terrestrial animals (Maynord and Loosli, 1979) and fish (NRC, 1973). The required amount of methionine has been investigated in common carp (Nose, 1979), chinook salmon (Halver et al.,1959), channel catfish (Harding et al., 1977), rainbow trout (Rumsey et al.,1983), sea bass (Thebault et al., 1985), channel catfish (Robinson et al., 1978), blue tilapia (Liou, 1989), red drum (Moon and Gatlin, 1991), Catla (Ravi and Devaraj, 1991), milkfish (Borlongan and Coloso, 1993), rohu (Murthy, 2002).

\section{Materials and Methods}

Fish used in this study were Rohu (Labeo rohita) juveniles obtained from a commercial hatchery. These juveniles were conditioned for about ten days before the experiment, during which time they were fed a diet containing $30 \%$ protein. The experiment was conducted in cement cisterns of $25 \mathrm{~m}^{3}$ size $(5 \times 5 \times 1 \mathrm{~m})$ with soil base at the College of Fisheries, Mangalore. The cisterns were thoroughly flushed with water and allowed to dry. They were then filled with freshwater drawn from 
an open well to a depth of $0.7 \pm 0.5 \mathrm{~m}$ prior to stocking and this level was maintained throughout the experimental period. Each cistern was stocked randomly with 10 fish weighing an average of $109.07 \pm 2.68 \mathrm{~g}$ and length $21.97 \pm 0.26 \mathrm{~cm}$. Each diet was fed to five replicate groups of fish, at a rate of $2 \%$ of the body weight of the fish for 60 days. A minimum of $50 \%$ of the population was collected from each tank at every two weeks interval to record growth in terms of weight and length. Water samples from each cistern were analyzed every week for dissolved oxygen, free carbon dioxide, total alkalinity, ammonia and $\mathrm{pH}$ following standard methods (APHA, 1998). Water temperature ranged $28.5-31.5^{\circ} \mathrm{C}$, alkalinity 42.27-49.05 ppm., dissolved oxygen 7.70-7.94 mg/l, pH 7.528.18 and total ammonia $0.19-0.23 \mu \mathrm{g} \mathrm{N} / 1$. The recorded parameters were within the range suitable for carp growth (Jhingran, 1991).

The ingredients used in the formulation of different experimental diets were soyabean meal, rice bran, corn flour, cottonseed meal, rapeseed meal, fish meal, sardine oil, vitamin mineral mixture, vit. $\mathrm{C}$, methionine (MetAMINO). All the ingredients were procured from the local market except MetAMINO which was supplied by M/S from Evonik Degussa India Pvt, Mumbai and were analyzed for proximate composition prior to formulation of the test diets employing standard methods (AOAC, 2005).

Moisture content was estimated by heating samples at $105{ }^{0} \mathrm{C}$ for $30 \mathrm{~min}$ and then cooling and weighing to a constant weight. Crude protein was analyzed using Kjeltec system (Tecater 1002 Distilling Unit), fat content by Soxtech system (Tecater 1043 Extraction Unit), fibre content by using Fibretech System (Tecater 1017 Hot Extractor). The ash content was determined by first drying the sample and then heating it in a muffle furnace at $550 \pm 10$ ${ }^{0} \mathrm{C}$ for $6 \mathrm{~h}$. Carbohydrate content was calculated as nitrogen free extract (NFE) by the difference method (Hastings, 1976).

Three experimental diets namely $\mathrm{T}_{0}, \mathrm{~T}_{1}$ and $\mathrm{T}_{2}$ with $30 \%$ protein content were formulated using the square method (Hardy, 1980). Diet $\mathrm{T}_{1}$ had $0.08 \%$ methionine and $\mathrm{T}_{2}$ had $0.48 \%$ methionine and without methionine supplementation served as control $\left(\mathrm{T}_{0}\right)$. The total daily ration of feed was divided into two equal meals and fed twice daily at the rate of $2 \%$ body weight during the experimental period.

The required quantities of ingredients were weighed accurately, mixed and hand kneaded to required consistency with just sufficient quantity of water (1:0.8) to get smooth dough. The dough so obtained was cooked under steam in a pressure cooker at $105^{\circ} \mathrm{C}$ for 20 to 30 minutes. The cooked dough was then cooled to room temperature rapidly by spreading in an enamel tray and required quantity of amino acid, sardine oil and vitamin-mineral premix were added, mixed and blended. The dough was extruded through a pelletizer having $3 \mathrm{~mm}$ diameter. Extruded pellets were dried in a hot air oven at $60^{\circ} \mathrm{C}$ till the moisture content was reduced to less than $10 \%$. The proximate compositions of the diets were determined according to standard methods (AOAC, 1995) and the amino acid compositions of the ingredients and diets were analyzed employing an amino acid analyzer (LKB model 415 Alfa plus). Diets were packed separately in high density polythene bags, labelled and stored in a dry place at room temperature for further use. Ingredients and proximate composition of the experimental diets are presented in Table 1.

The fishes were sampled once in a fortnight to assess the growth. The stocked fish were collected during each sampling and measured individually for growth parameters. After the experimental period of 60 days all the 
survived fishes were collected and their weight and survival data were recorded. The other growth parameters such as Absolute growth rate, Specific growth rate (SGR) and Feed conversion ratio (FCR) were calculated by using the following formulae.

Absolute growth rate $(\mathrm{g})=$ Final mean weight - Initial mean weight

Relative growth rate $(\%)=[($ Final mean weight - Initial mean weight) / Initial mean weight] $\mathrm{x} 100$

Specific growth rate $(\%)=[(\ln$ final weight ln initial weight) / Rearing period (day)] x100

Feed conversion ratio $=$ Total dry feed offered (g) / Total wet weight gain (g)

The physico-chemical parameters of water such as temperature, carbon dioxide, dissolved oxygen, ammonia and $\mathrm{pH}$ in all the experimental tanks were estimated. Standard methods (APHA, 1998) were employed for the analysis of the water quality parameters.

Super oxide anion production assay (NBT assay) was analysed immediately after the completion of experiment. The test was performed as described by Anderson and Siwicki (1993) in flat bottomed microtitre plates. The activated phagocytes (neutrophils and macrophages) were characterized by their ability to adhere to glass or plastic and produce oxygen free radicals. NBT in its reaction with oxygen free radicals was reduced to blue formazan, the extent of which was determined by Enzyme Linked Sorbent Assay (ELISA) reader at $620 \mathrm{~nm}$.

The experimental results were tabulated and analyzed statistically by using one-way analysis of variance (ANOVA) and Duncan's multiple range tests was used for mean separation (Duncan, 1955).

\section{Results and Discussion}

The result showed that dietary methionine levels had a significant effect on the final body weight, FCR, SGR and Super oxide anion production (Table 2 and 3). WG, SGR and Super oxide anion production (NBT) increased with the increasing dietary methionine level. Weight gained was significantly higher $(\mathrm{P}<0.05)$ in methionine incorporated diet i.e. $(314.00 \pm 8.12)$ in $\mathrm{T}_{0}$ followed by $\mathrm{T}_{1}(372.00 \pm 11.58)$ and $\mathrm{T}_{2}$ (412.00 \pm 23.10$)$. SGR also showed significantly increasing $(\mathrm{P}<0.05)$ trend when compared to control diet, $(1.69 \pm 0.04)$ in $\mathrm{T}_{0}$ followed by $\mathrm{T}_{1}(2.10 \pm 0.09)$ and $\mathrm{T}_{2}$ $(2.25 \pm 0.06)$. Super oxide anion production NBT significantly increased $(\mathrm{P}<0.05)$ in methionine incorporated diet than that of control diet from $(0.54 \pm 0.01)$ in $\mathrm{T}_{0}$ followed by $\mathrm{T}_{1}(1.12 \pm 0.15)$ and $\mathrm{T}_{2}(1.67 \pm 0.06)$. The highest values of WG, SGR and Super oxide anion production (NBT) occurred at the $0.48 \%$ followed by $0.08 \%$ and control dietary methionine level $(\mathrm{P}<0.05)$.

FCR decreased with increasing of dietary methionine level from $(1.20 \pm 0.05)$ in $T_{0}$ followed by $\mathrm{T}_{1} \quad(1.03 \pm 0.03)$ and $\mathrm{T}_{2}$ $(1.01 \pm 0.03)$. There was no significant effect on length of juvenile rohu fed with methionine incorporated diet.

It is a common practice to supplement aquafeeds with methionine. In this study methionine was added to improve the rohu's growth performance. The WG, SGR, FCR and Super oxide anion production of the rohu fed the un-supplemented experimental diet was lower than those of the rohu fed the methionine diets. Supplementation of methionine and/or lysine in diets has shown to improve the weight gain of channel catfish raised in ponds or aquaria (Reigh, 1999) as well as sea bream (Pagrus major) (Takagi et al., 2001). 
Table.1 Ingredients and chemical composition of experimental diets

\begin{tabular}{l}
$\begin{array}{l}\text { Diet ingredients } \\
\text { (g/1000 g feed) }\end{array}$ \\
\hline Soybean meal \\
\hline Rice bran \\
\hline Corn flour \\
\hline Cotton seed meal \\
\hline Rape seed meal \\
\hline Fish meal \\
\hline Sardine oil \\
\hline Vitamins and mineral mix (Agrimin forte) \\
\hline Vitamin-C \\
\hline Methionine \\
\hline Proximate composition (\%) \\
\hline Dry matter (\%) \\
\hline Total moisture $(\%)$ \\
\hline Total nitrogen \\
\hline Crude protein \\
\hline Crude fat \\
\hline Crude fibre \\
\hline Ash \\
\hline
\end{tabular}

\begin{tabular}{|c|c|c|}
\hline $\begin{array}{c}\mathrm{T}_{0} \\
\text { (Control) }\end{array}$ & $\begin{array}{c}\mathrm{T}_{1}(\mathbf{0 . 0 8 \%} \\
\text { methionine) }\end{array}$ & $\begin{array}{c}\mathrm{T}_{2}(\mathbf{0 . 4 8} \% \\
\text { methionine) }\end{array}$ \\
\hline 380.00 & 380.00 & 380.00 \\
\hline 330.00 & 329.20 & 325.20 \\
\hline 130.00 & 130.00 & 130.00 \\
\hline 50.00 & 50.00 & 50.00 \\
\hline 50.00 & 50.00 & 50.00 \\
\hline 30.00 & 30.00 & 30.00 \\
\hline 10.00 & 10.00 & 10.00 \\
\hline 10.00 & 10.00 & 10.00 \\
\hline 10.00 & 10.00 & 10.00 \\
\hline- & 0.80 & 4.80 \\
\hline $91.02 \pm 0.04$ & $91.38 \pm 0.04$ & $91.33 \pm 0.01$ \\
\hline $8.89 \pm 0.04$ & $8.34 \pm 0.04$ & $8.13 \pm 0.01$ \\
\hline $31.96 \pm 0.08$ & $32.07 \pm 0.26$ & $31.17 \pm 0.06$ \\
\hline $31.95 \pm 0.00$ & $32.32 \pm 0.05$ & $32.82 \pm 0.08$ \\
\hline $7.39 \pm 0.00$ & $8.79 \pm 0.06$ & $9.28 \pm 0.01$ \\
\hline $7.09 \pm 0.03$ & $7.01 \pm 0.04$ & $7.19 \pm 0.14$ \\
\hline $12.63 \pm 0.02$ & $11.19 \pm 0.10$ & $10.87 \pm 0.02$ \\
\hline
\end{tabular}

${ }^{1}$ Vitamins and mineral mix (mg kg-1 feed) (Vitamin A $700000 \mathrm{IU}$; Vitamin $\mathrm{D}_{3} 70000 \mathrm{IU}$; Vitamin E 250mg; Nicotinamide 1000mg; Cobalt 150mg; Copper 1200mg; Iodine 325mg; Iron 1500mg; Magnesium 6000mg; Potassium 100mg; Sodium 5.9mg; Manganese 1500mg; Sulphur 0.72\%; Zinc 9600mg; Calcium 25.5\%; Phosphorus $12.75 \%)$

Table.2 Weight gain, specific growth rate (SGR) and survival of rohu juvenile fed graded levels of methionine and control diet

\begin{tabular}{|c|c|c|c|c|c|}
\hline Diet & $\begin{array}{l}\text { Mean initial } \\
\text { weight }(\mathrm{g})\end{array}$ & $\begin{array}{l}\text { Mean final } \\
\text { weight }(\mathrm{g})\end{array}$ & $\begin{array}{l}\text { Mean weight } \\
\text { gain }(\mathrm{g})\end{array}$ & $\begin{array}{l}\text { Mean initial } \\
\text { length }(\mathbf{c m})\end{array}$ & $\begin{array}{l}\text { Mean final length } \\
(\mathbf{c m})\end{array}$ \\
\hline $\mathrm{T}_{0}$ & $114.42 \pm 4.25$ & $314.00 \pm 8.12^{\mathrm{a}}$ & $199.58 \pm 5.13^{\mathrm{a}}$ & $22.41 \pm 0.21$ & $29.08 \pm 0.46^{\mathrm{a}}$ \\
\hline $\mathrm{T}_{1}$ & $106.20 \pm 6.83$ & $372.00 \pm 11.58^{\mathrm{b}}$ & $265.80 \pm 9.16^{\mathrm{b}}$ & $22.00 \pm 0.35$ & $30.81 \pm 0.23^{\mathrm{b}}$ \\
\hline $\mathrm{T}_{2}$ & $106.60 \pm 3.74$ & $412.00 \pm 23.10^{\mathrm{b}}$ & $305.40 \pm 20.53^{\mathrm{b}}$ & $21.51 \pm 0.73$ & $30.62 \pm 0.32^{\mathrm{b}}$ \\
\hline
\end{tabular}

The means with different superscript in each column indicate a significant difference $(\mathrm{P}<0.05)$. Each value is a Mean \pm SE ( $n=5$ replicates).

Table.3 Weight gain, specific growth rate (SGR) and survival of rohu juvenile fed graded levels of methionine and control diet

\begin{tabular}{|c|c|c|c|c|}
\multicolumn{1}{l|}{ Diet } & FCR $(\%)$ & SGR $(\%)$ & Survival (\%) & NBT-test \\
\hline $\mathrm{T}_{0}$ & $1.20 \pm 0.05^{\mathrm{a}}$ & $1.69 \pm 0.04^{\mathrm{a}}$ & 100 & $0.54 \pm 0.01^{\mathrm{a}}$ \\
\hline $\mathrm{T}_{1}$ & $1.03 \pm 0.03^{\mathrm{b}}$ & $2.10 \pm 0.09^{\mathrm{b}}$ & 100 & $1.12 \pm 0.15^{\mathrm{b}}$ \\
\hline $\mathrm{T}_{2}$ & $1.01 \pm 0.03^{\mathrm{b}}$ & $2.25 \pm 0.06^{\mathrm{b}}$ & 100 & $1.67 \pm 0.06^{\mathrm{c}}$ \\
\hline
\end{tabular}

The means with different superscript in each column indicate a significant difference $(\mathrm{P}<0.05)$. Each value is a Mean $\pm \mathrm{SE}(\mathrm{n}=5$ replicates $)$ 
Young ones of channel catfish required methionine at $2.34 \%$ of dietary protein in the absence of cystine for proper growth, (Harding et al., 1977). Incorporation of methionine, lysine and cystine in diet enhanced FBW, SGR, FCR in Sea bass (Dentrarshus laborax) larvae (Salama et al., 2013).

The FCR of the cobia fed the methionine diet was significantly lower than that of the cobia fed the coated methionine diets (Chi et al., 2014).

Mc Cartney (1967), however, found that brook trout supplemented with $2 \%$ methionine showed improved growth and higher body protein when a high protein, high calorie diet was fed, but lower growth and body protein when fed a low protein and lower calorie diet. Similar results were obtained by Blaza et al., (1982) in growing dogs where digestibility of energy improved significantly when methionine supplementation was increased in the diet.

Superoxide anion production is considered to be one of the most important microbicidal components and is an important index of immune function (Secombes, 1990).

Ali (2006) observed that, deficiency of methionine and lysine causes of all the blood parameters examined, the red blood cell count and mean cell volume showed significant decrease than the control.

Other haematological values were lower than that of the normal values. The RBCs and WBCs counts showed lower than the the control, also, Chaiyapoom et al., (2006) noticed that, hematocrit value, $\mathrm{Hb} \%$ were lower than the control with deficiency of methionine and/or lysine or with each other. In human, an amino acid mixture containing methionine was shown to increase plasma concentration of cholecystokinin and bile salt and lipase output (Colombel et al., 1988).

The present study established that Labeo rohita fed with diet containing supplemented methionine showed a significant difference in growth and immune response. The growth, survival and immune response in Labeo rohita was higher in fish fed with methionine incorporated diets than in the control diet fed fish.

Among the two levels, $0.48 \%$ methionine showed better performance than $0.08 \%$ methionine.

\section{Acknowledgement}

Authors are thankful to $\mathrm{M} / \mathrm{S}$ from Evonik Degussa India Pvt, Mumbai, for supplying methionine (MetAMINO) to conduct the research.

\section{References}

Ali, A.S. (2006). Immune response of broiler chicks to DL-Methionine supplementation at different ages. International J. of Poult. Sci., 5 (2): 169 - 172.

Anderson, R.A. (1998). Chromium, glucose in the prevention and control of diabetes. J. Amer. Coll. Nutr., 17: 548-555.

AOAC. (1975). Official methods of analysis, $12^{\text {th }}$ edn, W. Harwitz, (Ed). Association of Analytical Chemists, Washington D. C.

Arai, S., Nose, T. and Hashimoto, Y. (1972). Amino acids essential for the growth of eels, Anguilla anguilla and A. japonica. Bull. Jpn. Soc. Sci. Fish., 38: 753-759.

Austic, R.E. (1978). Nutritional interactions of amino acids. Feedstuffs, 29: 24-26.

Blaza, S.E., Burger, I.H., Holme, D.W. and Kendall, P.T. (1982). Sulfur-containing amino acid requirements of growing dogs. J. Nutr., 112: 2033-2042.

Borlongan, I.G. and Pazaro, M.M. (1991). Effect of dietary lipid sources on growth, survival and fatty acid composition of sea bass 
(Lates calcarifer Blotch) fry. Bamidgeh, 43: 95-102.

Borlongan, I.G. and Relicardo, Coloso, M., (1993). Requirements of juvenile milk fish (Chanos chanos) for essential amino acids. J. Nutr., 123: 125-132.

Chaiyapoom, B., Takawan, S. and Ratchadaporn, C. (2006). Effect of adding methionine Hydroxy analogue as Methionine source at the commercial requirement recommendation on production performance and evidence of Ascitis syndrome of male broiler chicks fed corn soybean based. International. J. of Poult. Sci. 5(8): $744-752$.

Chi, S., Tan, B., Dong, X., Yang, Q. and Liu, H. (2014). Effects of supplemental coated or crystalline methionine in low-fishmeal diet on the growth performance and body composition of juvenile cobia Rachycentron canadum (Linnaeus). Chinese Journal of Oceanology and Limnology. 32 (6): 297-1306.

Choo, P.S., Smith, T.K., Cho, C.Y. and Ferguson, W. (1991). Dietary excesses of leucine influence on growth and body composition of rainbow trout. J. Nutr., 121: 1932-1939.

Gatlin, D.M. (2002). Nutrition and fish health. In: J. E Halver, R. W. Hardy, (Eds). Fish Nutrition. Academic Press, San Diego, CA, USA., pp 671-702.

Halver, J.E., Delong, D.C. and Mertz, E.T. (1959). Methionine and cystine requirements of chinook salmon. (Abstr.) Fed. Proc., 18: 527.

Harding, D.E., Allen, O.W. and Wilson, R.P. (1977). Sulfur amino acid requirement of Channel catfish: L-methionine and Lcytine. J. Nutr., 107: 2031-2035.

Harper, A.E., Benevenga, N.J. and Wohlhueter, R.M. (1970). Effects of ingestion of disproportionate amount of amino acids. Physiol. Rev., 50: 428-458.

Jhingran, V.G. (1982). Fish and Fisheries of India. Hindustan Publ. Corp. New Delhi. P.666.

Li, P., Gatlin, D.M. (2005) Nucleotide nutrition in fish: current knowledge and future applications. Aquaculture. 108: 231-243.

Maynard, L.A. and Lossli, J.K. (1969). Animal nutrition. Mc Graw-Hill, New York, p. 613.

Mc Cartney, T.H. (1967). The effect of dietary protein level and methionine supplementation on the growth, chemical composition, and total sulfur of fingerling brook trout. Cortland Hatchery Conservation Department, Albany, N. Y., 20-24.

Murthy, H.S. (2002). Indian major carps. In: C.D. Webster and C.E. Lim (ed.), Nutrient requirement and feeding of finfish for aquaculture. Wallingford, UK, CABI Publishin. pp: 262-272.

Murthy, H.S. and Varghese T.J. (1996b). Dietary requirements of the Indian major carp, Labeo rohita for total aromatic amino acids. Israeli Journal of Aquaculture-Bamidgeh. 48(2): 78-83.

Murthy, H.S. and Varghese T.J. (1996c). Quantitative dietary requirement of threonine for the growth of Indian major carp, Labeo rohita. J. Aquaculture Tropics, 11: 1-7.

Murthy, H.S. and Varghese, T.J. (1995). Arginine and histidine requirement of the Indian major carp, Labeo rohita. Aquacult. Nutr., 1: 235-239.

Murthy, H.S. and Varghese, T.J. (1996a). Quantitative dietary isoleucine requirement for growth and survival of Indian major carp, Labeo rohita (Hamilton) fry. Indian Journal of Experimental Biology 34: 11411143.

Murthy, H.S. and Varghese, T.J. (1998). Total sulphur amino acid requirement of the Indian major carp, Labeo rohita (Hamilton). Aquaculture Nutrition, 4: 6165.

Nose, T. (1979). Summary report on the requirements of essential amino acids for carp. In: Finfish nutrition and fish feed technology. J. E. Halver and K. Tiews (Eds.). Vol. I. Heenemann, Berlin, pp. 145156.

NRC (National Research Council), (1993). Nutrient requirements of fish. Washington, DC, USA, National Academy Press, 114 p.

Phillips, A.M., Jr., Livingston, D.L. and Poston, H.A. (1965). The effect of changes in protein quality, calorie sources and calorie levels upon the growth and chemical composition of brook trout. Cortland Hatchery Report no. 34. Fish Res. Bull. no. 
29, New York State Conservation Department, Albany, N. Y., 6-14.

Ravi, J. and Devaraj, K.V. (1991). Quantitative essential amino acid requirements for growth of Catla catla (Hamilton). Aquaculture, 96: 281-291.

Reigh, R.C. (1999). Production characteristics of pond-raised channel catfish Ictalurus punctatus fed diets with and without animal protein for three growing seasons. J. World Aquacult. Soc., 30: 154-160.

Robinson, E.H. and Wilson, R.P. (1985). Nutrition and feeding. In: Channel catfish culture. Tucker, C.S. (Ed.) Elsevier, Amsterdam, pp. 323-404.

Salama, M., Fatma,-Abed, H.E.L, Alaa, A., Dahhar, E. (2013). Effect of Amino Acids (Lysine and Methionine + Cyctine) Supplementation Rate on Growth Performance and Feed Utilization of Sea Bass (Dentrarshus laborax) Larvae. Journal of the Arabian Aquaculture Society. 8 (1) 37-52.

Santiago, C.B. and Lovell, R.T. (1988). Amino acid requirements for growth of Nile tilapia. J. Nutr., 118: 1540-1546.

Secombes, C.J. (1990). Isolation of salmonid macrophages and analysis of their killing activity. In JS Stolen, TC Fletcher, D Anderson, BS Robertson, WB van Muiswinkel, eds. Techniques in fish immunology. Vol. I. Fair Haven, NJ: SOS
Publications, pp. 137-154.

Takagi, S., Shimeno, S., Hosokawa, H. and Ukawa, M. (2001). Effect of lysine and methionine supplementation to a soy protein concentrate diet for red sea bream Pagrus major. Fisheries. Sci., 67: 1 088-1 096.

Thebault, H., Alliot, E. and Pastoureaud, A. (1985). Quantitative methionine requirement of juvenile sea bass (Dicentrarchus labrax). Aquaculture, 50: 75-87.

Walton, M.J. (1985). Aspects of amino acid metabolism in teleost fish. pp. 47-67. In: C.V. Cowey, A.M. Mackie and J.G. Bell (Eds.). Nutrition and Feeding in Fish. Acad. Press, London.

Wilson, R.P. (1985). Amino acids and protein requirements of fish. In: C. B. Cowey, A.M. Mackie, and J.G. Bell (Eds.). Nutrition and feeding in fish. Academic press, London. p. 1-16.

Wilson, R.P. (1986). Amino acids and protein requirements of fish. In: Nutrition and feeding in fish. C.B. Cowey, A.M. Mackie and J.G. Bell, (Eds.). Academic press, London.

Wilson, R.P., Allen, O.W.Jr., Robinson, E.H. and Poe, W.E. (1978). Tryptophan and threonine requirements of fingerling channel catfish. J. Nutr., 108: 1595-1599.

\section{How to cite this article:}

Nilima Priyadarshini, H. Shivananda Murthy, A. Hosseinpoor Zelaty and Swain, H. 2018. Effect of Dietary Supplementation of Methionine on Growth, Survival and Immune Response of Indian Major Carp, Labeo rohita. Int.J.Curr.Microbiol.App.Sci. 7(02): 2202-2209. doi: https://doi.org/10.20546/ijcmas.2018.702.265 